\title{
Thermal Performance of Heat Pipe Array in Battery Thermal Management
}

\author{
Chaoyi WAN
}

\begin{abstract}
In the present study, the thermal performance of a power battery cooling system using copper tubes and heat pipes was compared. The effects of coolant flow rate, coolant inlet temperature, and input power were discussed by numerical methods. The numerical computation results showed that heat pipe could more significantly enhance the heat transfer performance of the battery cooling system than the copper rod. Within the scope of this study, the heat pipe reduced the maximum temperature by $41,6 \%-60,9 \%$. The distributions of the temperature ratio of the battery surface, together with the heat flux and streamlines around the heat pipe condenser were also illustrated.
\end{abstract}

Keywords: battery thermal management; heat pipe; heat transfer enhancement; temperature difference

\section{INTRODUCTION}

Lithium-ion battery is the promising energy storage equipment for electric vehicles and hybrid electric vehicles for its high energy density $[1,2]$. The optimum working temperature of the lithium battery is $25{ }^{\circ} \mathrm{C}-40{ }^{\circ} \mathrm{C}$ [3-6], the maximum temperature difference should not exceed $5{ }^{\circ} \mathrm{C}$ in one battery pack $[7,8]$; otherwise, it may cause serious safety problems $[6,7]$. The heat pipe cooling system which uses liquid-gas phase change without consuming extra power has become the most promising cooling method in lithium-ion battery thermal management system with excellent heat transfer performance and rapid response capability $[3,4,9,10]$.

The power battery generates heat more than $50 \mathrm{~W}[11$, 12], and more during acceleration and other high charging or discharging conditions. Rao et al. [4] conducted experimental research which shows that the maximum temperature of the battery surface can be controlled below $50{ }^{\circ} \mathrm{C}$ when heat generation of the battery is less than 50 $\mathrm{W}$. However, the maximum temperature difference is about $8{ }^{\circ} \mathrm{C}$. The heat load should not exceed $30 \mathrm{~W}$ to maintain the surface temperature difference within $5{ }^{\circ} \mathrm{C}$. The experiment studied by Wang et al. [13] pointed out that the battery temperature can stay below $70{ }^{\circ} \mathrm{C}$ when the heat generation per cell is between $20-40 \mathrm{~W}$. Or the amount of heat generation cannot exceed $10 \mathrm{~W}$ in order to achieve the maximum temperature below $40{ }^{\circ} \mathrm{C}$. Ye et al. [11] found that the heat transfer coefficient of the heat pipe condenser surface decreased significantly along the flow passage, causing unevenness of the battery temperature. Dummy heat pipes and copper fins could enhance the heat transfer and temperature uniformity. Ye et al. [14] also pointed out that the addition of fins at the heat pipe condenser sections has a significant effect on lowering the maximum temperature and the temperature difference on battery surface.

More information is needed to study the influence parameters of the heat pipe cooling system on a lithium battery. In this paper numerical investigations were conducted on heat transfer characteristics and flow details in a heat pipe cooling system for the high-power lithium battery. The validity of the numerical models and grids used in this study was carefully checked and calibrated by comparing with experimental data in the literature. Amounts of indicators such as temperature, heat flux, and pressure loss were extracted to characterize the heat performance of heat pipe cooling system.

\section{NUMERICAL SETUP}

\subsection{Geometry Models and Simplifications}

Fig. 1 shows a configuration of the heat pipe cooling system for a prismatic battery pack. Between two prismatic batteries $(118 \times 63 \times 13 \mathrm{~mm})$ were sandwiched evaporator sections of four heat pipes. The heat generated in the battery is transferred to the condenser section through the heat pipe and then emitted into the coolant flow through the cooling passage $(300 \times 60 \times 12 \mathrm{~mm})$. Each heat pipe was flattened from tubular condenser $(\varnothing=6,0 \mathrm{~mm})$ to rectangular evaporator section $(2,0 \times 8,5 \mathrm{~mm})$. The copper cooling system is designed as similar as the heat pipe cooling system except that the heat pipes are turned to pure copper rods. Cross section radius of vapor core is $0,002 \mathrm{~m}$. The total length of the heat pipe is $0,198 \mathrm{~m}$. The porosity of the wick region is 0,50 . The copper cooling system is designed similar to the heat pipe cooling system except that the heat pipes are turned to pure copper rods.

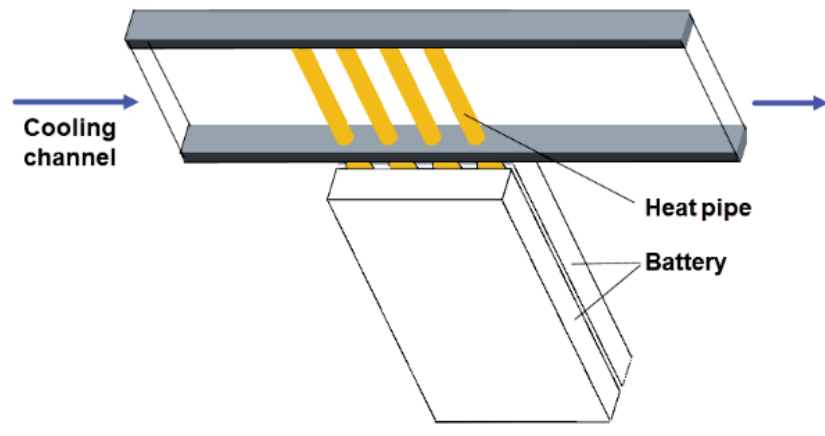

Figure 1 The configuration of the heat pipe cooling system for a prismatic battery pack

It is complex and time-consuming to model all details for a battery pack cooled by heat pipe for phase changes and other phenomena in heat pipe. Even in the case of simulating one heat pipe, high computational resources are necessitated to characterize the mass and heat transfer during transient charging or discharging of the cell. Thus, one more efficient approach for numerical computation is adopted. The thermal behavior of a heat pipe on battery cooling would be treated as a thermal network of various 
components, and then the transient behavior can be described by first order linear ordinary differential equations [15]. Additionally, solving electro-chemical reactions of a battery is also too complicated for only presenting the thermal behavior of battery cell (multi-layer structure). Therefore, a simplified model without considering electro-chemical reactions is applied to present the heat generation of the battery, as well as the thermal properties of a multi-layered battery cell. This approach is well validated by comparisons with experimental and numerical studies and is applied in many pieces of literature $[1,9,11,15]$.

\subsection{Model Formulation of the Heat Pipe 2.3.1 Copper Shell}

The thermal properties of copper were applied directly to the copper shell during this simulation because the heat transfer through the copper shell of the heat pipe is entirely conduction.

\subsubsection{Wick Region}

In the present study, a heat pipe with a higher maximum heat transfer limit than the target heat load has been selected to avoid drying during operation. The wick region was considered as a porous structure filled with water. A widely accepted model developed by Chi et al. [16] can be used to calculate the effective thermal conductivity of the wick region $k_{\text {wick}}$ :

$k_{\text {wick }}=\frac{k_{1}\left[\left(k_{1}+k_{\mathrm{s}}\right)-(1-\varepsilon)\left(k_{1}-k_{\mathrm{s}}\right)\right]}{\left[\left(k_{1}+k_{\mathrm{s}}\right)+(1-\varepsilon)\left(k_{1}-k_{\mathrm{s}}\right)\right]}$

where $k_{1}$ and $k_{\mathrm{s}}$ are respectively the thermal conductivity of working fluid and sintered copper powder porous wick, and $\varepsilon$ is the porosity. In this study, the effective thermal conductivity of the wick region was calculated to be 1,814 $\mathrm{Wm}^{-1} \mathrm{~K}^{-1}$.

The volumetric averaged density of the mixture of water and sintered copper powder porous wick could be utilized to determine the density of the wick region by Eq. (2), and the specific heat capacity is obtained according to Eq. (3).

$$
\begin{aligned}
& \rho_{\text {wick }}=\varepsilon \rho_{1}+(1-\varepsilon) \rho_{\mathrm{s}} \\
& C_{\text {wick }}=\left[\varepsilon \rho_{1} C_{1}+(1-\varepsilon) \rho_{\mathrm{s}} C_{\mathrm{s}}\right] / \rho_{\text {wick }}
\end{aligned}
$$

where $r_{\text {wick}}, r_{\mathrm{l}}, r_{\mathrm{s}}$ are respectively the densities of the wick, working fluid and copper powder, $C_{\text {wick }}, C_{\mathrm{l}}, C_{\mathrm{s}}$ are respectively the specific heat capacity of the wick, working fluid and copper powder, and $\varepsilon$ is the porosity.

\subsubsection{Vapor Core}

The vapor flow was considered incompressible, laminar and fully developed. By assuming the relationship between pressure drop and temperature drop in accordance with the Clapeyron equation and the ideal gas law [17, 18], the effective thermal conductivity of the vapor core in a tubular heat pipe can be calculated by Eq. (4) [17] $k_{\mathrm{vapor}}=\frac{r_{\mathrm{v}}^{2} L^{2} \rho P_{\mathrm{v}}}{8 \mu R T^{2}}$

where $r_{\mathrm{v}}$ is the cross-section radius of the vapor core. $L$ is the latent heat of working fluid. $\rho, P_{\mathrm{v}}, \mu, R$ and $T$ is respectively the density, the saturation pressure, the dynamic viscosity, the gas constant per unit mass and the temperature of the water vapor. The $k_{\text {vapor was calculated as }}$ $4,69 \times 10^{6} \mathrm{Wm}^{-1} \mathrm{~K}^{-1}$ using the properties of saturated water vapor at a temperature of $40^{\circ} \mathrm{C}$.

\subsection{Thermal Model of the Battery}

Two aluminum blocks of the same size as some commercial power battery were used to simulate batteries $[4,13,19,20]$. It is assumed that during the entire operation process, the heat generation rate of the battery is a constant value which is regarded as the maximum power during the highest sustainable constant-current discharge rate. In the present research, the heat generation rate is in the range of $20-80 \mathrm{~W}$ per cell.

\subsection{Numerical Procedures}

In this calculation, numerical studies were performed by the commercial CFD software-ANSYS Workbench 17.2 FLUENT using a local parallel solver in a doubleprecision mode. Heat radiation transfer is negligible and was not considered.

Block-structured grids with hexahedral elements were employed to realize the spatial discretization of the domain models. Cell orthogonality was ensured by introducing multiple O-grid blocks for heat pipes. Denser girds were applied in the non-slip boundary regions where the flow and temperature gradients are greater, i.e., the area around heat pipes and the endwall of the coolant channel. The grid independence test was performed by gradually refining the mesh size (in this study, three different meshes containing 2628477, 4737970 and 7895174 cells, respectively) to ensure that the mesh size has little impact on the results. The control parameter for grid independence test was the maximum temperature on the battery surface. According to the procedure described [21], the grid convergence index (GCI) was 2,81\%. Fig. 2 shows the mesh used in this numerical investigation.

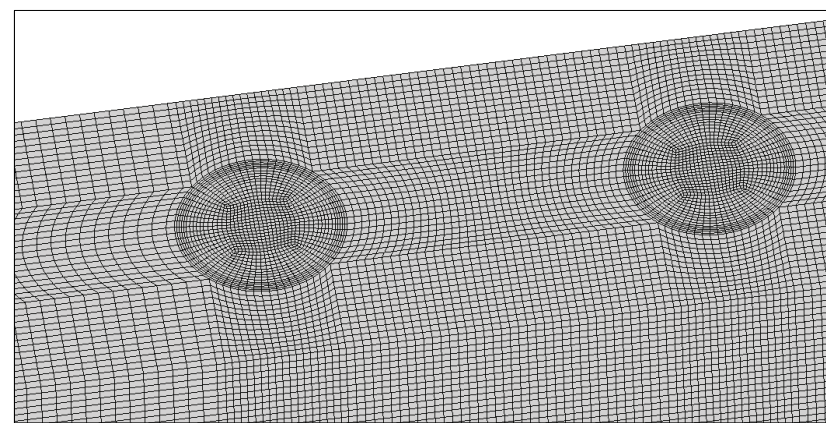

Figure 2 The hexahedral mesh used in the present numerical study

\section{MODEL VALIDATION}

The results obtained by the computation procedure were well compared with the published experimental data 
of Liang [20]. All materials, boundary conditions, and data processing methods are modified according to the experiment of Liang [20]. The computation models include the heat transfer in the solid wall and in the fluid, which is coupled to solve energy equations automatically. The surface of the channel and the insulation section of heat pipes are treated as isolation and no-slip boundaries. The two batteries have a constant volume heat generation rate. At the inlet of the channel, constant velocity was applied. Laminar is used to calculate the viscous due to the inlet Reynolds number. Data are plotted in Fig. 3 for comparison. As illustrated, the maximum deviation between the numerical computation results in this research and the data from the literature [20] were kept within $10 \%$. Thus, the numerical model is considered to be reliable and can be applied to predict the heat performance of the heat pipe cooling system for the battery based on the above validation.

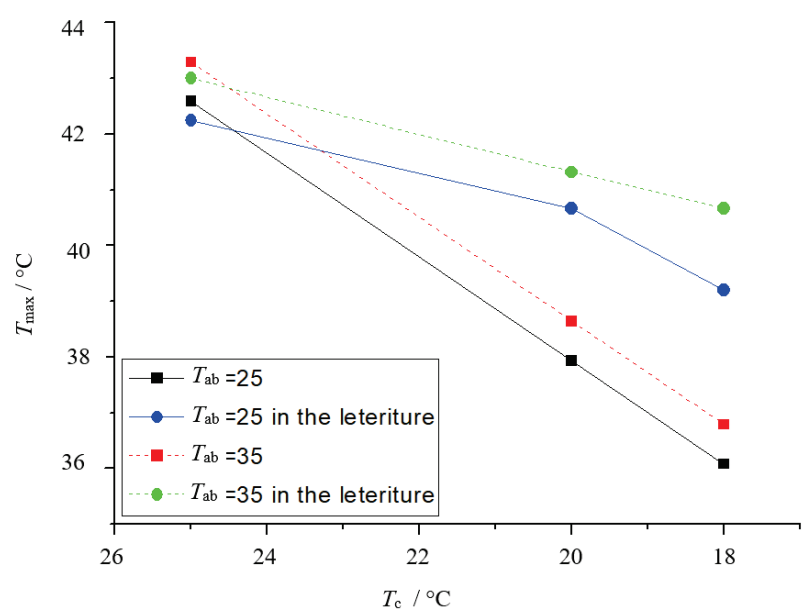

Figure 3 Results of maximum temperature varied with coolant inlet temperature obtained by CFD and experimental data from Liang [20] for comparison

\section{RESULTS AND DISCUSSION}

\subsection{Effects of Coolant Flow Rate}

In this section, the effect of coolant flow rate on the battery surface temperature while using heat pipes and copper rods is compared. The input power is set at 40 W/cell while the coolant inlet temperature $T_{\mathrm{c}}$ is set as $25{ }^{\circ} \mathrm{C}$. The cooling flow rate ranges from $0,5 \mathrm{~L} / \mathrm{min}$ to 8 $\mathrm{L} / \mathrm{min}$. The maximum temperature $\left(T_{\max }\right)$, average temperature $\left(T_{\mathrm{avg}}\right)$, and temperature difference $(\Delta T)$ of battery surface with different coolant flow rates for both configurations are shown in Fig. 4.

The trend of $T_{\max }$ and $T_{\text {avg }}$ for both heat pipe and copper rod is similar. At first, the $T_{\max }$ and $T_{\text {avg }}$ reduced rapidly with the increased coolant flow rate while gradually being gentle when the coolant flow rate reaches $2 \mathrm{~L} / \mathrm{min}$, and the temperature difference of the battery surface $\Delta T$ almost keeps constant.

While the coolant flow rate changes from $0,5 \mathrm{~L} / \mathrm{min}$ to $8 \mathrm{~L} / \mathrm{min}$, the maximum temperature on the battery surface by copper rod changes from $107,81{ }^{\circ} \mathrm{C}$ to $84,24{ }^{\circ} \mathrm{C}$, decreased by $21,9 \%$, and that by heat pipe changes from $52,74{ }^{\circ} \mathrm{C}$ to $39,77^{\circ} \mathrm{C}$, decreased by $24,6 \%$. The heat pipe reduced the maximum temperature by $51,1 \%-52,8 \%$. While the coolant flow rate changes from $0,5 \mathrm{~L} / \mathrm{min}$ to 8 $\mathrm{L} / \mathrm{min}$, the temperature differences by copper rod change from $19,34{ }^{\circ} \mathrm{C}$ to $18,51^{\circ} \mathrm{C}$, and that by heat pipe changes from $2,08{ }^{\circ} \mathrm{C}$ to $1,74{ }^{\circ} \mathrm{C}$. The heat pipe reduced the maximum temperature by $89,3 \%-90,6 \%$. Compared to copper rods, heat pipes significantly reduce the maximum temperature and temperature difference on the battery surface.

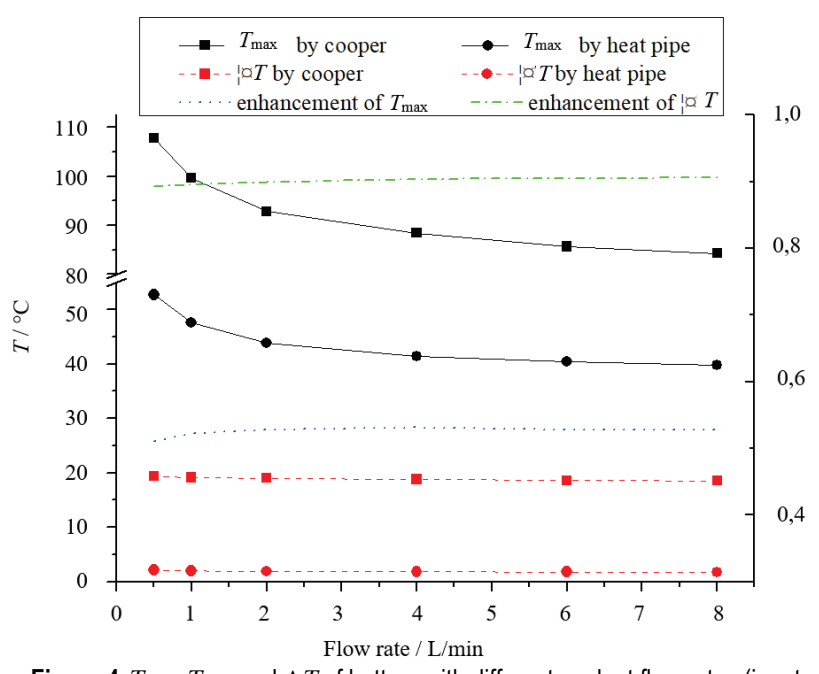

Figure $4 T_{\max }, T_{\text {avg }}$, and $\Delta T$ of battery with different coolant flow rates (input power is $40 \mathrm{~W} /$ cell under $\left(T_{\mathrm{c}}=25^{\circ} \mathrm{C}\right)$

\subsection{Effect of Coolant Inlet Temperature}

In this section, the input power is set at $40 \mathrm{~W} /$ cell while the coolant flow rate is set at $2 \mathrm{~L} / \mathrm{min}$ to study the effect of coolant inlet temperature on the heat pipe cooling system. The coolant inlet temperature ranges from $25^{\circ} \mathrm{C}$ to $45^{\circ} \mathrm{C}$. The maximum temperature $\left(T_{\max }\right)$, average temperature $\left(T_{\text {avg }}\right)$, and temperature difference $(\Delta T)$ of battery surface under different coolant inlet temperatures of copper rod and heat pipe are shown in Fig. 5.

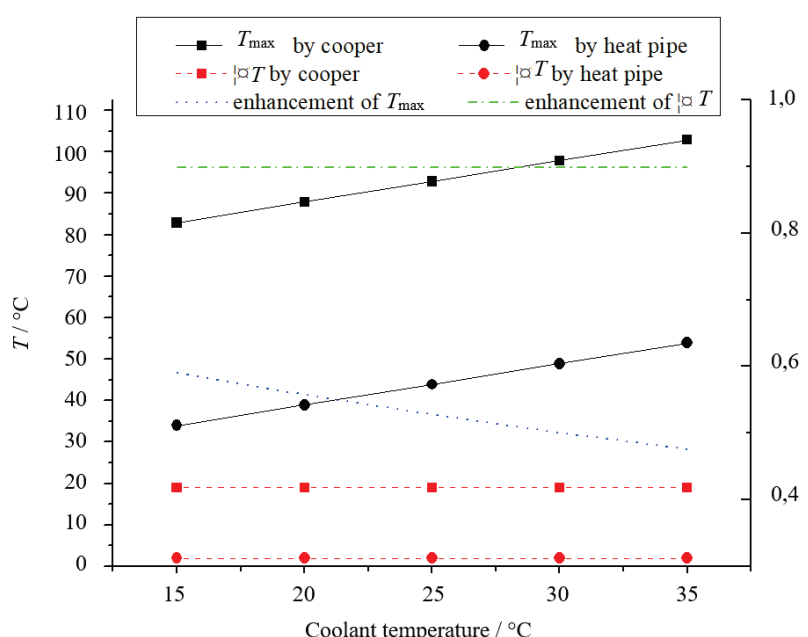

Figure $5 T_{\max }, T_{\text {avg }}$ and $\Delta T$ of battery with different coolant inlet temperatures (input power is $40 \mathrm{~W} /$ cell under $q_{v}=2 \mathrm{~L} / \mathrm{min}$ )

Both $T_{\max }$ and $T_{\text {avg }}$ of cooper rod and heat pipe increase linearly as coolant inlet temperature increases. As coolant inlet temperature increases from $15{ }^{\circ} \mathrm{C}$ to $35^{\circ} \mathrm{C}$, the maximum temperature $T_{\max }$ of copper rod increases from $82,85^{\circ} \mathrm{C}$ to $102,85^{\circ} \mathrm{C}$, the enhancement is $24,1 \%$; and the data of heat pipe is from $33,91{ }^{\circ} \mathrm{C}$ to $53,91{ }^{\circ} \mathrm{C}$, the enhancement is $59,0 \%$. The heat pipe reduced the 
maximum temperature by $59,1 \%-47,6 \%$. The temperature uniformity is less affected by coolant inlet temperature. The temperature difference $(\Delta T)$ is always around $19,0^{\circ} \mathrm{C}$ and $1,9{ }^{\circ} \mathrm{C}$. The heat pipe reduced the maximum temperature by $89,8 \%$. Compared to copper rods, heat pipes significantly reduce the maximum temperature and temperature difference on the battery surface.

\subsection{Effect of Input Power}

In this section, the effect of input power on the temperature of the battery surface cooling by cooper rod and heat pipe is studied. The cooling flow rate is set at 2 $\mathrm{L} / \mathrm{min}$ under $T_{\mathrm{c}}=25^{\circ} \mathrm{C}$, and the input power ranges from $20 \mathrm{~W}$ to $80 \mathrm{~W}$. The maximum temperature $\left(T_{\max }\right)$, average temperature $\left(T_{\mathrm{avg}}\right)$, and temperature difference $(\Delta T)$ of battery surface with different input powers of the battery are shown in Fig. 6.

As shown in Fig. 6, $T_{\max }$, and $T_{\text {avg }}$ as well as $\Delta T$ significantly increase as the input power increases. While the input power changes from $20 \mathrm{~W}$ to $80 \mathrm{~W}$, the maximum temperature of copper rod increases from $58,84{ }^{\circ} \mathrm{C}$ to $160,85^{\circ} \mathrm{C}$, enhancement of $173,4 \%$; and that data of heat pipe increases from $34,38{ }^{\circ} \mathrm{C}$ to $62,97{ }^{\circ} \mathrm{C}$, increase of $83,2 \%$. The heat pipe reduced the maximum temperature by $41,6 \%-60,9 \%$. The temperature difference of copper rod increases from $9,49{ }^{\circ} \mathrm{C}$ to $37,96^{\circ} \mathrm{C}$, and the data of heat pipe increase from $0,96{ }^{\circ} \mathrm{C}$ to $3,86{ }^{\circ} \mathrm{C}$. The heat pipe reduced the maximum temperature by $89,8 \%$.

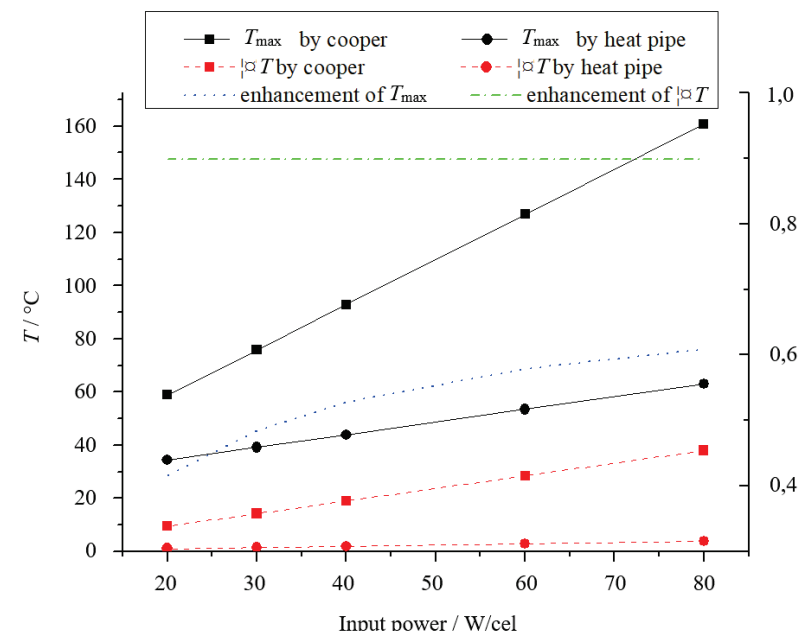

Figure $6 T_{\max }, T_{\text {avg }}$ and $\Delta T$ of battery with different input power (mass flow rate $q_{v}=2 \mathrm{~L} / \mathrm{min}$ under coolant inlet temperature $T_{\mathrm{c}}=25^{\circ} \mathrm{C}$ )

\subsection{Comparison of Local Temperature Distribution between Cooper and Heat Pipe}

The distribution of temperature ratio $\left(T / T_{\mathrm{avg}}\right)$ can represent the temperature difference, and that of battery surface by copper rod and heat pipe is displayed in Fig. 7. In the copper rod cooling structure, the surface temperature gradient of the battery is mainly the longitudinal temperature gradient. In the heat pipe cooling structure, the surface temperature gradient distribution of the battery is very different from that of the copper tube. Temperature gradient occurs between the longitudinal and lateral directions. The temperature gradient along the length of heat pipe is caused by heat conduction from bottom to top, and the temperature gradient along the coolant streamwise is very likely resulted from a reduction in the effective heat transfer coefficient in the flow direction. The increasing coolant flow rate enhances the turbulence intensity, which enhances the mixing of hot water around heat pipe condensers and the cold water on the periphery. It contributes to the increase of the effective heat transfer coefficient in the flow direction and the reduction of the temperature gradient downstream the coolant.
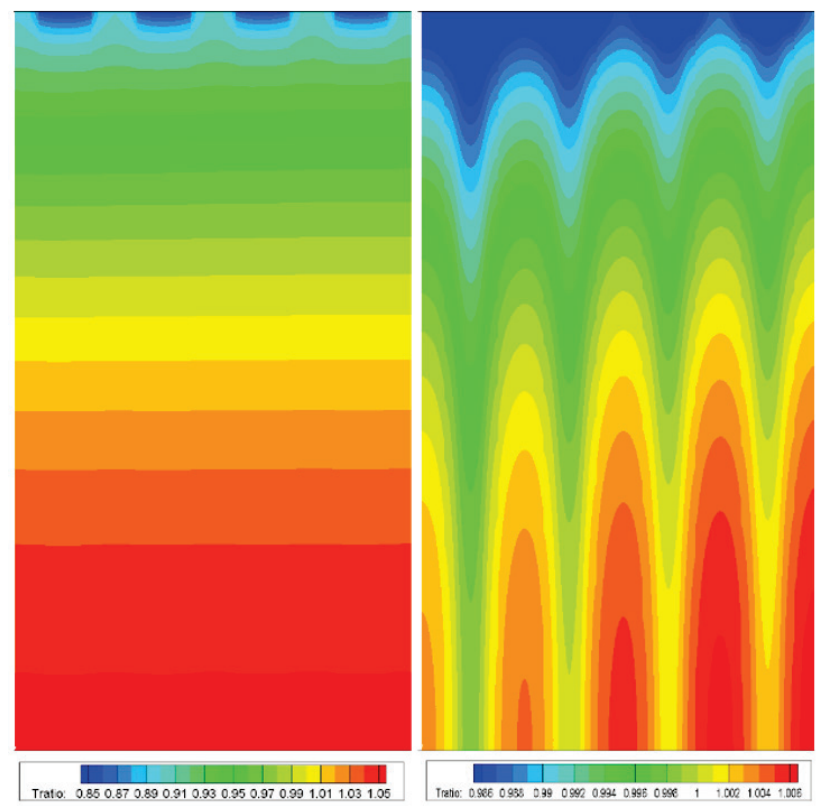

(a) copper rod (b) heat pipe

Figure 7 The distribution of temperature ratio $\left(T / T_{\text {avg }}\right)$ of battery $\left(q_{v}=2 \mathrm{~L} / \mathrm{min}, 40 \mathrm{~W} /\right.$ cell under $\left.T_{\mathrm{c}}=25^{\circ} \mathrm{C}\right)$

\subsection{Heat Transfer Distribution in the Heat Pipe Condenser Sections}

The thermal performance is significantly affected by the convective heat transfer between the coolant and the cooling structures. Fig. 8 displays streamline and convective heat transfer coefficients at the wall of the copper rod and heat pipe condenser section while the coolant flow rate is $q_{\mathrm{v}}=2 \mathrm{~L} / \mathrm{min}$ under coolant inlet temperature $T_{\mathrm{c}}=25^{\circ} \mathrm{C}$, and the input power of the battery is $40 \mathrm{~W} /$ cell. As can be seen, fewer vortices are produced in the entire flow field for the flow is mainly laminar. It can be seen that the surface heat exchange of the copper rod is very uneven, and the heat exchange is mainly concentrated near the root wall of the battery. On the principle battery side, there is almost no heat exchange. In addition, away from the battery end, there is almost no heat exchange. Compared to copper rods, heat pipe heat transfer is largely unaffected by the height direction, but there is a difference between the circumferential directions. 


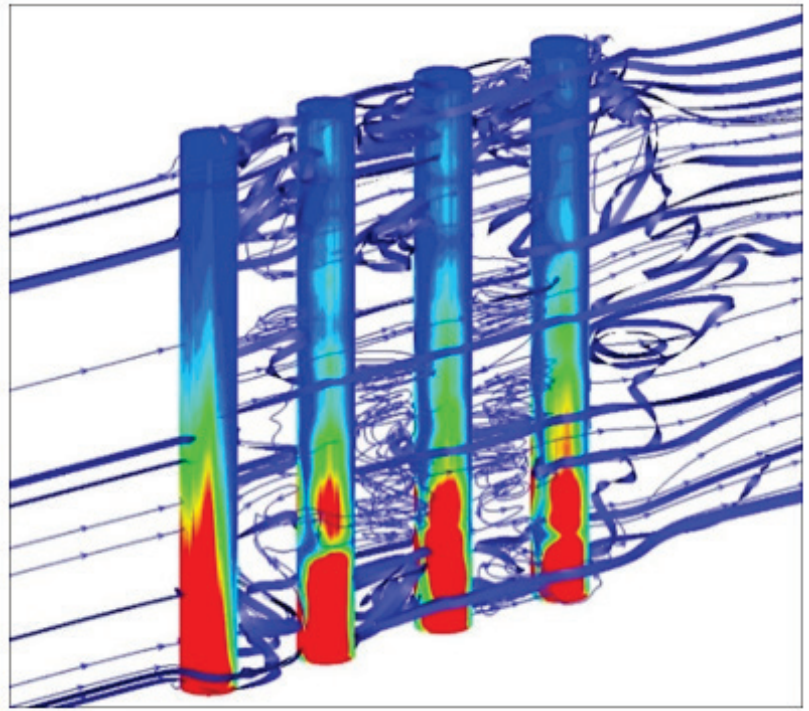

(a) cooper rod

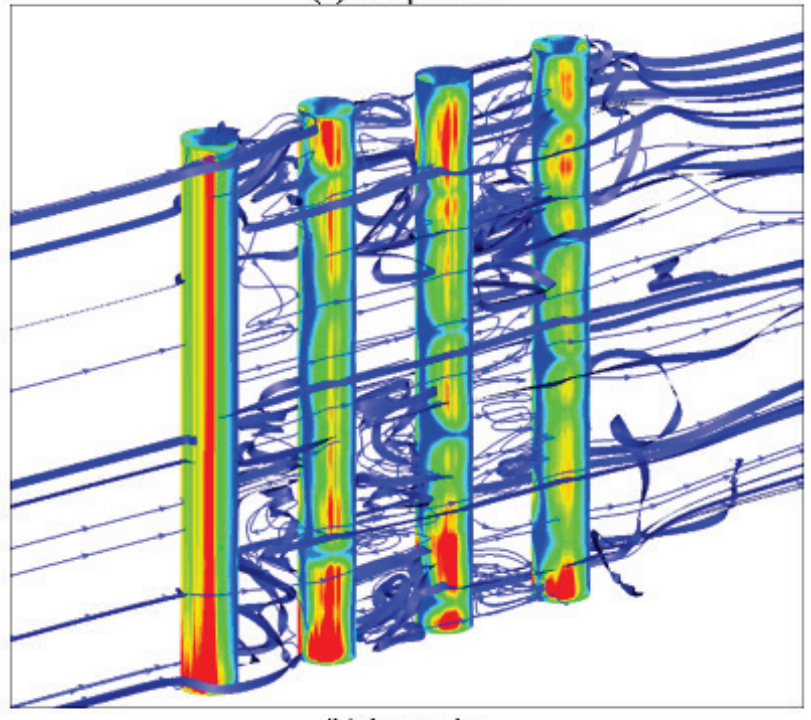

(b) heat pipe

$\begin{array}{lllllllll}\text { Boundary heat flux: } 5000 & 10000 & 15000 & 20000 & 25000 & 30000 & 35000 & 40000\end{array}$

Figure 8 Streamline and Nusselt number on the (a) copper rods and (b) heat pipe condenser sections

\section{CONCLUSION}

In the present study, the thermal performance of a power battery cooling system using copper tubes and heat pipes was compared. The effects of coolant flow rate, coolant inlet temperature, and input power were discussed by numerical methods. Numerical models and procedures are carefully validated and calibrated with experimental results in the literature. The model and approach demonstrated considerable accuracy and were then employed to sensitivity analysis. Amounts of indicators such as temperature, heat flux, and pressure loss were extracted to describe the characteristics of the heat pipe cooling system. The results can provide some useful guidance for the heat pipe cooling system. Several main conclusions can be drawn as follows:

(1) Compared to copper rods, heat pipes significantly reduce the maximum temperature and temperature difference on the battery surface respectively by $41,6 \%$ $60,0 \%$ and $89,8 \%-90,6 \%$.

(2) The distributions of the temperature ratio $T / T_{\text {avg }}$ display the temperature uniformity of the battery surface, together with the heat flux and streamlines respectively on the copper rod and heat pipe condenser explains the effect of coolant flow rate, coolant inlet temperature and input powers on the performance of the heat pipe cooling system.

\section{Acknowledgments}

This work was supported by the Natural Science Foundation of Jiangsu Province (Grants No. BK20170317).

\section{REFERENCES}

[1] Choi, Y. S. \& Kang, D, M. (2014). Prediction of thermal behaviors of an air-cooled lithium-ion battery system for hybrid electric vehicles. Journal of Power Sources, 270, 273 280. https://doi.org/10.1016/j.jpowsour.2014.07.120

[2] Etacheri, V., Marom, R., Elazari, R., et al. (2011). Challenges in the development of advanced Li-ion batteries: a review. Energy \& Environmental Science, 4(9). 32433262. https://doi.org/10.1039/c1ee01598b

[3] Tran, T. H., Harmand, S., \& Sahut, B. (2014). Experimental investigation on heat pipe cooling for Hybrid Electric Vehicle and Electric Vehicle lithium-ion battery. Journal of Power Sources, 265(2014). 262-272. https://doi.org/10.1016/j.jpowsour.2014.04.130

[4] Rao, Z., Wang, S., Wu, M., et al. (2013). Experimental investigation on thermal management of electric vehicle battery with heat pipe. Energy Conversion and Management, 65(2013). 92-97. https://doi.org/10.1016/j.enconman.2012.08.014

[5] Waldmann, T., Wilka, M., Kasper, M., et al. (2014). Temperature dependent ageing mechanisms in Lithium-ion batteries-A Post-Mortem study. Journal of Power Sources, 262(2014). 129-135. https://doi.org/10.1016/j.jpowsour.2014.03.112

[6] Bandhauer, T. M., Garimella, S., \& Fuller, T. F. (2011). A critical review of thermal issues in lithium-ion batteries. Journal of the Electrochemical Society, 158(3). R1-R25. https://doi.org/10.1149/1.3515880

[7] Troxler, Y., Wu, B., Marinescu, M., et al. (2014). The effect of thermal gradients on the performance of lithium-ion batteries. Journal of Power Sources, 247(2014). 1018-1025. https://doi.org/10.1016/j.jpowsour.2013.06.084

[8] Wang, T., Tseng, K., Zhao, J., et al. (2014). Thermal investigation of lithium-ion battery module with different cell arrangement structures and forced air-cooling strategies. Applied Energy, 134(2014). 229-238. https://doi.org/10.1016/j.apenergy.2014.08.013

[9] Greco, A., Cao, D., Jiang, X., et al. (2014). A theoretical and computational study of lithium-ion battery thermal management for electric vehicles using heat pipes. Journal of Power Sources, 257(2014). 344-355. https://doi.org/10.1016/j.jpowsour.2014.02.004

[10] Rao, Z., Huo, Y., \& Liu, X. (2014). Experimental study of an OHP-cooled thermal management system for electric vehicle power battery. Experimental Thermal and Fluid Science, 57(2014). 20-26. https://doi.org/10.1016/j.expthermflusci.2014.03.017

[11] Ye, Y., Saw, L. H., Shi, Y., et al. (2015). Numerical analyses on optimizing a heat pipe thermal management system for lithium-ion batteries during fast charging. Applied Thermal Engineering, 86(2015). 281-291. https://doi.org/10.1016/j.applthermaleng.2015.04.066

[12] Ye, Y., Saw, L. H., Shi, Y., et al. (2014). Effect of thermal contact resistances on fast charging of large format lithium ion batteries. Electrochimica Acta, 134(2014). 327-337. 
https://doi.org/10.1016/j.electacta.2014.04.134

[13] Wang, Q., Jiang, B., Xue, Q., et al. (2015). Experimental investigation on EV battery cooling and heating by heat pipes. Applied Thermal Engineering, 88(2015). 54-60. https://doi.org/10.1016/j.applthermaleng.2014.09.083

[14] Ye, Y., Shi, Y., Saw, L. H., et al. (2016). Performance assessment and optimization of a heat pipe thermal management system for fast charging lithium ion battery packs. International Journal of Heat and Mass Transfer, 92(2016). 893-903. https://doi.org/10.1016/j.jiheatmasstransfer.2015.09.052

[15] Zuo, Z. \& Faghri, A. A. (1998). Network thermodynamic analysis of the heat pipe. International Journal of Heat and Mass Transfer, 41(11). 1473-1484.

https://doi.org/10.1016/S0017-9310(97)00220-2

[16] Chi, S. (1976). Heat pipe theory and practice: a sourcebook.

[17] Prasher, R. S. A. (2003). Simplified conduction based modeling scheme for design sensitivity study of thermal solution utilizing heat pipe and vapor chamber technology. Journal of Electronic Packaging, 125(3). 378-385. https://doi.org/10.1115/1.1602479

[18] Wei, X. \& Sikka, K. (2006). Modeling of vapor chamber as heat spreading devices. Proceedings of the Thermal and Thermomechanical Proceedings $10^{\text {th }}$ Intersociety Conference on Phenomena in Electronics Systems, 2006 ITHERM 2006, F, IEEE.

[19] Ling, Z., Chen, J., Fang, X., et al. (2014). Experimental and numerical investigation of the application of phase change materials in a simulative power batteries thermal management system. Applied Energy, 121(2014). 104-113. https://doi.org/10.1016/j.apenergy.2014.01.075

[20] Liang, J., Gan, Y., \& Li, Y. (2018). Investigation on the thermal performance of a battery thermal management system using heat pipe under different ambient temperatures. Energy Conversion and Management, 155(2018). 1-9. https://doi.org/10.1016/j.enconman.2017.10.063

[21] Celik, I., Ghia, U., Roache, P., et al. (2008). Procedure for estimation and reporting of uncertainty due to discretization in CFD applications. J Fluids Eng, 130(7). 078001. https://doi.org/10.1115/1.2960953

\section{Contact information:}

\section{Chaoyi WAN}

(Corresponding author)

School of Automobile and Traffic Engineering,

Jiangsu University of Technology,

Changzhou 213001, Jiangsu, P. R. China

E-mail: wanchaoyi_jsut@yeah.net 